planet earth. It was a circle, the classical image of the universe, after all. The bed today has become a portable universe, equipped with every possible technology of communication. A midcentury fantasy has turned into mass reality. Working in bed in the gig economy is increasingly becoming a norm for the marginalized and disenfranchised. It is no longer about the quasi-aristocratic, or dandy, male figure laboring in bed but a shift in the organization of labor, perhaps at the threshold of postlabor. The bed has become infrastructural, a crucial node floating in global networks.

What is the architecture of this new space and time? What is the nature of this new interior in which we have collectively decided to check ourselves in? What is the architecture of this prison in which night and day, work and play are no longer differentiated and we are permanently under surveillance, even as we sleep in the control booth? New media turns us all into inmates, even as we celebrate endless connectivity. We have all become "a contemporary recluse," as Hefner put it half a century ago.

In Laura Poitra's film Citizenfour, we see Edward Snowden up close for days on end sitting on his bed in a Hong Kong hotel, surrounded by laptops, communicating with journalists in the room and around the world about the secret world of massive global surveillance. The biggest invasion of privacy in the history of the planet is revealed from bed and dominates all media. The most public figure in the world at that moment is a recluse. Architecture has been inverted.

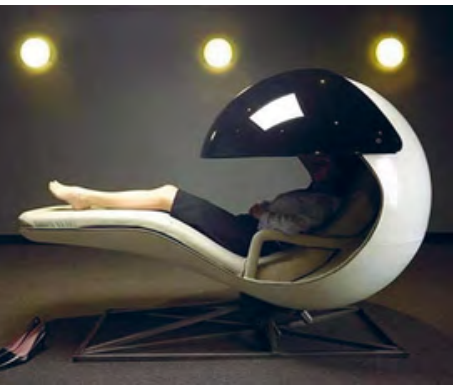

EnergyPod by MetroNaps, "the world's first chair designed for napping in the work place,“ 2007

\title{
Dennis Pohl \\ Tools, Infrastrukturen und Räume des relationalen Forschens \\ Tools, Infrastructures, and Spaces of Relational Research
}

Die Vermittlung von Wissen ist stets medial gebunden. Medien sind wiederum Teil des normierten Regelwerks einer Infrastruktur, worunter Keller Easterling eine „diffuse 
Matrix aus Details und wiederholbaren Formeln" versteht, mit denen zirkulierendes Wissen gefestigt wird. ${ }^{1}$ Oder wie es Reinhold Martin formuliert: „Infrastruktur ist alles, was sich wiederholt." 2

So gibt einerseits diese logistische Dimension den epistemischen Wirkungsradius von Medien gewissermaßen vor, wenn spätestens seit der Akteur-Netzwerk-Theorie von verteilter Handlungsmacht zwischen Menschen und Dingen und einer damit einhergehenden Neubestimmung des Sozialen die Rede ist. ${ }^{3}$ Andererseits eröffinet diese infrastrukturelle Bindung zugleich einen Handlungsspielraum für die Aneignung von Medien, womit eine Veränderung der durch die infrastrukturelle Matrix vorgegebenen ökonomischen, politischen und sozialen Bedingungen bewirkt werden kann. Genau auf diese Gegenüberstellung weisen die in diesem Band besprochenen Beiträge hin: Museen können entweder als hegemoniale Container kolonialer Vergangenheiten dienen oder spekulativer Möglichkeitsraum radikaler pädagogischer Praktiken sein, beispielsweise für die „Vermittlung von etwas, das es noch nicht gibt" (Sternfeld/Adamczak). Ausstellungen können Plattform globalökonomischer „altermoderner“ Vorstellungen sein oder als Träger nicht-westlicher Epistemologien agieren (Holert). Fotografien der Appropriation Art können Medien von celebrity culture sein und sexistische Blickregime fetischisieren oder einer künstlerischen Praxis der „Remediatisierung von Film- bzw. Fernsehbildern“ dienen (Weingart). Essayfilme können entweder zeitgenössische kulturelle Identität reduzieren oder in visueller und auditiver Vielbezüglichkeit ästhetische „Dividuation“ und kulturelle Teilhabe herstellen (Ott/Salhab). Sprecher_innenpositionen können entweder mittels diskursiver Netzwerke epistemische Privilegien konstituieren oder mittels spekulativer relationaler Techniken zu neuen Welt(sicht)en beitragen (Thiele). Staatsbürgerschaften können entweder als gegeben vorausgesetzt werden oder in aktivistischen, theoretischen und künstlerischen Auseinandersetzungen hinterfragt, neu

1 Easterling, Keller / Seuß, Rita: „Die infrastrukturelle Matrix“, in: Zeitschrift für Medienwissenschaft, Jg. 7, H. 12 (Medien/Architekturen), 2015, S. 68-78, hier: S. 68.

2 Graw, Isabelle / Martin, Reinhold / Rottmann, André: „Bestimmen Medien unsere Lage? Überlegungen zur transatlantischen Kittler-Rezeption", in: Texte zur Kunst, Nr. 98 (Medien), Juni 2015, S. 47-81.

3 Seier, Andrea: „Kollektive, Agenturen, Unmengen: Medienwissenschaftliche Anschlüsse an die Actor-Network-Theory", in: Zeitschrift für Medienwissenschaft, Jg. 1, H. 1, 2009, S. 132-135. 
verkörpert und verändert werden (Peters). Wie diese Fälle zeigen, ist die Remediatisierung also eine Bedingung für ein Gefüge aus Kulturtechniken, Apparaten, Diskursen und Institutionen und kann zudem einen medienkritischen Umgang mit jenem Wissen, das darin zirkuliert, fördern. Museum, Ausstellung, Fotografie, Film, Sprecher_in - ebenso Staatsbürgerschaft als Medium des Rechts - sind jedoch keine singulären Akteur_innen, die einzig kultur- und medientechnischen Funktionen des Übertragens, Speicherns und Verarbeitens dienen, sondern entfalten ihre Wirkmächtigkeit erst in einer technoid-humanoiden Infrastruktur aus hybriden Beziehungen. Mit Susan Leigh Star gesprochen, sind Infrastrukturen per definitionem „unsichtbar" und immer in "soziale Anordnungen und Technologien“ eingelassen, ${ }^{4}$ womit sich auch die Wirkungen dieser Beziehungen jenseits der sichtbaren Prozesse von Produktion und Konsum aufhalten, wie Nicole Starosielski herausgearbeitet hat. ${ }^{5}$ Hinter den von Beatriz Colomina besprochenen Bildern von Yoko Onos und John Lennons Bed-ins wird schließlich im Sinne Martin Heideggers auch das Bett zum Gestell. Onos und Lennons Bett-Revolte kann deshalb nur stattfinden, solange die Protagonist_innen im wahrsten Sinne des Wortes eingebettet sind in eine Medienökonomie von Kameras, Mikrofonen und Boulevardblättern, die ihr virtuelles Dasein in Zirkulation bringt. Diese Praxis stellvertretend für das Aufkommen einer neuen post-fordistischen Arbeitsweise zu betrachten, in der das Bett zur zentralen Produktionsund Reproduktionsstätte wird, verweist umso deutlicher auf die ausbeuterischen Beziehung(sweis)en, die die aktuellen medienökonomischen Dispositionen hervorbringen. Schließlich ist im Bett zu arbeiten auch für den ausgeklügelten Medienkapitalisten Hugh Hefner nur möglich, sofern seine zweifelhafte Produktivität durch die Arbeit des medial verschalteten Frauenkörpers kompensiert werden kann - in einer Infrastruktur, die Brigitte Weingart zufolge den „Topos der Frau als Bild"6 verwertet und gewinnbringend abschöpft. $\mathrm{Ob}$ diese medienökonomische Infrastruktur jedoch eine

4 Star, Susan Leigh: „Die Ethnografie von Infrastruktur“ (1999), in: dies.: Grenzobjekte und Medienforschung, Bielefeld 2017, S. 419-436, hier: S. 420; siehe dazu auch Schabacher, Gabriele: „Unsichtbare Stadt. Zur Medialität urbaner Architekturen“, in: Zeitschrift für Medienwissenschaft, Jg. 7, H. 12 (Medien/Architekturen), 2015, S. 79-90.

5 Starosielski, Nicole: The Undersea Network, Durham (NC)/London 2015.

6 Weingart, Brigitte: „Fame Is the Name of the Game“: Aneignung und celebrity culture, S. 202 in diesem Band. 
unveränderbare Gegebenheit sein muss, stellt insbesondere der Beitrag von Helen Pritchard, Jara Rocha und Femke Snelting zur Disposition. Darin stellen sie die Forderung nach feministischen Ansätzen in der aktiven Einflussnahme mittels künstlerischer Praktiken und Verantwortung gegenüber der epistemischen Relevanz von Infrastrukturen, die über den von Geovisualisierungs-Software programmierten Blick auf den Planeten Erde hinausgehend politische Veränderungen erzeugen und vielleicht somit auf Orit Halperns Frage nach einem planetaren Design einen möglichen Ansatz liefern. Abseits eines Technikdeterminismus ließe sich demnach Friedrich Kittlers berühmter Satz in die Umkehrformel bringen: ,Unsere Lage bestimmt die Medien', oder präziser: den Medienumgang. ${ }^{7}$ Umso deutlicher wird darin die Frage nach care und Verantwortung im Rahmen einer medienkritischen Praxis, gerade weil ,unsere Lage niemals unschuldig ist. Letzten Endes beruht diese hegemonial-epistemische Lage, wie Halpern aufzeigt, auf kolonialem Wissen oder nuklearen Tests.

Sofern Infrastrukturen (Universitäten eingeschlossen) sicherstellen sollen, dass sich Abläufe, Verfahren und Positionen wiederholen und allein im Fall ihres Fehlens oder der Störung sichtbar werden, ${ }^{8}$ liegt es vielleicht umso mehr bei medienkritischen Praktiken, Fragen von Gender und Ethnizität ins Spiel zu bringen und dadurch Differentiale, Deviationen und Störungen der Infrastruktur hervorzurufen, die epistemisch konstitutiv sind und als solche wahr- und ernst genommen werden. Nicht zuletzt wirft die Relationalität von Infrastrukturen auch die Frage auf, ob diese jenseits von Dienstbarkeitsarchitekturen auch eine affektive Wirkung haben und als Basis für neue soziale Gefüge dienen können. Kann es im Umgang mit medialen Bedingungen eine neue geteilte Verantwortung geben, die eine nicht-unschuldige Lage als Ausgangspunkt nimmt, um eine neue Medienund somit Wissenspolitik zu betreiben?

The act of mediating knowledge is - as the verb suggests always bound to a medium. At the same time, media are part of a normed infrastructure that Keller Easterling defines as a "matrix of details and repeatable formulas" constituting

7 „Medien bestimmen unsere Lage, die (trotzdem oder deshalb) eine Beschreibung verdient", Kittler, Friedrich: Grammophon, Film, Typewriter, Berlin: Brinkmann \& Bose 1986, S. 3.

8 Siehe dazu Graham, Stephen / Thrift, Nigel: „Out of Order. Understanding Repair and Maintenance", in: Theory, Culture \& Society, Bd. 24, Nr. 3, 2007, S. 1-25. 
circulating knowledge. ${ }^{9}$ Or as Reinhold Martin suggests: "Infrastructure is what repeats." 10

On the one hand, this logistical dimension predetermines the epistemic scope of media, to which Actor-Network-Theory prescribes a distributed agency between humans and things that calls for a reconsideration of what is social.

On the other hand, this infrastructural condition opens up a range of interventions for the appropriation of media that makes it possible to change economic, political, and social relations defined by the infrastructural matrix. It is precisely this juxtaposition, in particular, that is addressed by the contributions in this edited volume. Museums can serve either as hegemonic containers of colonial pasts or be considered as the speculative arena of radical pedagogical practices, i.e., by "mediating something that doesn't exist yet" (Sternfeld and Adamczak). Exhibitions can be either platforms of global-economic "altermodern" conceptions or act as bearers of non-Western epistemologies (Holert). Photographs of appropriation art can either be media of celebrity culture and hence fetishize sexist regimes of vision, or they can support an artistic practice of "remediatization of film and television images" (Weingart). Essay films can either reduce contemporary cultural identity or produce aesthetic "dividuation" and cultural participation with the means of visual and sonic equivocality (Ott and Salhab). Speaker positions can either constitute epistemic privileges by means of discourse networks or contribute to new world(view)s with speculative relational techniques (Thiele). Citizenships can be either assumed as given or they can be questioned, newly embodied, and changed through activist, theoretical, and artistic struggles (Peters). As these examples show, remediatization is a condition for the network of cultural techniques, apparatuses, discourses, and institutions and can contribute to a media-critical handling of the knowledge that circulates within.

Museum, exhibition, photography, film, speaker - even citizenship as a medium of law - are nevertheless not singular actors that purely serve the cultural- and media-technical functions of transmission, storage, and processing. Rather, they unfold their efficacy solely in a technohumanoid

9 Easterling, Keller, Extrastatecraft: The Power of Infrastructure, London 2014, p. 9.

10 Graw, Isabelle, Martin, Reinhold, and Rottmann, André, "Do Media Determine Our Situation? Reflections on the Transatlantic Reception of Friedrich Kittler," in Texte zur Kunst, no. 98, “Medien,” June 2015, p. 76. 
infrastructure of hybrid relations. Infrastructures are, to speak with Susan Leigh Star, by definition "invisible" and always "sunk into and inside of other structures, social arrangements and technologies." 11 The effects of these relations consequently also lie beyond the visible processes of production and consumption, as Nicole Starosielski has shown. ${ }^{12}$ Beyond the images of Yoko Ono's and John Lennon's Bed-Ins discussed by Beatriz Colomina, even the bed becomes a Heideggerian Gestell. Ono's and Lennon's bed revolution is only made possible as long as the protagonists are literally embedded in a media-economy of cameras, microphones, and tabloids that bring their virtual existence into circulation. Regarding this practice as representative for the rise of a new post-Fordist mode of work, in which the bed becomes the central place of production and reproduction, points even more insistently to the exploitative relation(ship)s that are revealed by current media-economical dispositions. Even the clever mediacapitalist Hugh Hefner is only able to work in bed as long as his doubtful productivity is compensated by the work of the female body as connected by media - an infrastructure that utilizes and profitably skims the "topos of the woman as an image," to use Brigitte Weingart's terms. ${ }^{13}$ Whether this media-economic infrastructure has to be an unchangeable assumption is questioned, in particular, by the contribution of Helen Pritchard, Jara Rocha, and Femke Snelting. The authors claim feminist approaches for an active influence on and care for the epistemic relevance of infrastructures that produce political differences by programming the gaze on the planet earth with geovizualization software. This is a practice that could be a response to Orit Halpern's demand for new forms of planetary design. Overcoming a technological determinism, Friedrich Kittler's famous phrase could be reversed: "Our situation determines our media," or at least the way we relate to it. ${ }^{14}$ What becomes even more urgent is the question of care and responsibility in the framework of a media-critical practice, exactly because "our" situation is never innocent. In the end, this hegemonic-

11 Star, Susan Leigh, "The Ethnography of Infrastructure," in American Behavioral Scientist 43, no. 3, November 1999, p. 381.

12 Starosielski, Nicole, The Undersea Network, Durham, NC / London 2015.

13 Weingart, Brigitte, "Fame Is the Name of the Game': Aneignung und celebrity culture," p. 202 in this volume.

14 "Media determine our situation, which - in spite or because of it - deserves a description." Kittler, Friedrich, Gramophone, Film, Typewriter, translated by Goeffrey Winthrop-Young and Michael Wutz, Stanford 1999, p. xxxix. 
epistemic situation is founded on colonial knowledge and nuclear tests, as Halpern has shown.

Since infrastructures (including universities) are made to ensure the repetition of processes, operations, and positions, and only become visible in case of a lack or error, mediacritical practices perhaps become even more relevant for introducing questions about gender and ethnicity in order to evoke differentials, deviations, and errors of the infrastructure that are perceived as epistemologically constitutive and taken serious as such. ${ }^{15}$ Ultimately, the relationality of infrastructures brings up the question of whether these have an affective dimension beyond their mere functions as service architecture and can therefore serve as a basis for new social relations. Can there be a new shared care in relating to media conditions that take the non-innocent situation as a starting point to perform new politics of media and therefore of knowledge?

\section{Maximilian Haas in conversation with Alice Chauchat, Gradinger/Schubot and Jeremy Wade How to Relate in Contemporary Dance?}

"How to relate?" is not at all a secondary question to the practice of contemporary dance - as if there were movement first that could then relate to something or not. Rather - mediated through bodies, through affect, sensing, imagination, rules, etc. - this question might even form the core of the artistic process through which dance emerges. While the notion of choreography is usually tied to a post/structuralist conception of writing dance - inventing choreographic languages and iterative texts to be interpreted first by the dancers and then by the spectators - the notion of dance is conceived of as a corporeal and situational artistic practice, which organizes and stratifies itself according to that which (with dance theorist Erin Manning) can be called "relationscapes."1 While choreography is thus primarily concerned with form and meaning, dance is functionally contingent on the factors and parameters

15 Graham, Stephen and Thrift, Nigel, "Out of Order: Understanding Repair and Maintenance," in Theory, Culture \& Society, vol. 24, no. 3, 2007, pp. 1-25.

1 Manning, Erin, Relationscapes: Movement, Art, Philosophy. Cambridge, MA 2009. 